\title{
Effective Solar Concentration on Solar PV Panel
}

\author{
Sathyanarayana $\mathbf{P}^{1}$, Abhishek PV ${ }^{2}$, Sachin K Shetty ${ }^{3}$, Sudhir Pai $^{4}$, Srinidhi $\mathbf{M}^{5}$ \\ Assistant professor, Dept. of Electrical and Electronics, S.D.M. Institute of Technology, Ujire (D.K), India ${ }^{1}$ \\ 8th Semester, Dept. of Electrical and Electronics, S.D.M. Institute of Technology, Ujire (D.K), India ${ }^{2,3,4,5}$
}

\begin{abstract}
Solar Photovoltaic system is a power system designed to supply usable solar power by means of photovoltaics. The total power generated by a photovoltaic panel depends on light intensity falling over the surface. The variation of light intensity plays a predominant role in solar power generation. The effect of light intensity on a photovoltaic power generation could be extrapolated using PSIM software. The result shows that if the light concentration on a solar cell increases the power output also increases.
\end{abstract}

Keywords: P-V cell, P-V array, Irradiation, Pyranometer, I-V and P-V characteristics.

\section{INTRODUCTION}

According to The International Energy agency the present World energy consumption is about 10 Terawatts(TW) per year, and by 2050, it is projected to be about 30 TW [1] .The sun delivers $2 \times 10^{\mathbf{1 4}} \mathrm{kW}$ energy on the Earth, which is about 10,000 times more than the present energy consumption. The energy that the Earth receives from the sun in just one hour is equal to the total amount of energy consumed by humans in one year.

There is a growing need for energy in the world and since the traditional energy sources based on the fossil fuels are limited and will be exhausted in future, PV solar energy is considered a promising energy source candidate. Largescale application of PV solar energy will also contribute to the diversification of energy sources resulting in some more equal distribution of energy sources in the world [2].

The direct conversion of solar radiation into electricity is often described as a photovoltaic (PV) energy conversion because it is based on the photovoltaic effect. In general, the photovoltaic effect means the generation of a potential difference at the junction of two different materials in response to visible or other radiation.

Apart from generating electricity, solar energy has a vast area of applications such as water heating, lighting, and crop drying. The various solar devices can be either active or passive depending upon the way they detain, convert and distribute solar energy. The intensity of a solar radiation is estimated to be $1369 \mathrm{~W} / \mathrm{m}^{2}$ and is generally referred as Solar Constant [3].

The solar panels are part of a complete PV solar system, which depending on the application, comprises batteries for electricity storage, dc/ac inverters that connect a PV solar panel to the electrical grid, and other miscellaneous electrical components or mounting elements.

\section{SOLAR PV PANEL}

The solar energy conversion into electricity takes place in a semiconductor device that is called a solar cell. A solar cell is a unit that delivers a certain amount of electrical power that is characterized by an output voltage and current. A number of solar cells are connected together to form a solar panel, also called a PV module. For a largescale generation of solar electricity the solar panels are connected together into a solar array. [5]

Solar cells are described as being photovoltaic irrespective of whether the source is sunlight or artificial light. They are used as a photo detector (for example infrared detectors), detecting light or other electromagnetic radiation near the visible range, or measuring light intensity

In a place like Ujire $\left(12^{\circ} 59^{\prime} 27.0^{\prime \prime} \mathrm{N} 75^{\circ} 20^{\prime} 27.8^{\prime \prime} \mathrm{E}\right)$, solar energy can be effectively used for more than six months (October to May). The average radiation on this part of geographical location is shown below and also the Figure 2 represents the same [6].

Table 1.Annual Average: $5.12\left(\mathrm{kWh} / \mathrm{m}^{2} /\right.$ day $)$

\begin{tabular}{|l|l|}
\hline JANUARY & 5.49 \\
\hline FEBRUARY & 6.07 \\
\hline MARCH & 6.52 \\
\hline APRIL & 6.39 \\
\hline MAY & 5.60 \\
\hline JUNE & 3.75 \\
\hline JULY & 3.55 \\
\hline AUGUST & 4.07 \\
\hline SEPTEMBER & 4.93 \\
\hline OCTOBER & 4.74 \\
\hline NOVEMBER & 5.02 \\
\hline DECEMBER & 5.27 \\
\hline
\end{tabular}




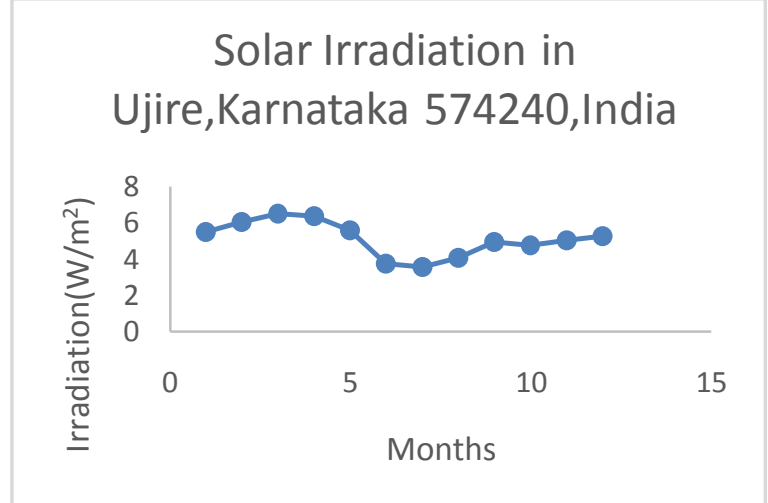

Figure 2: Graphical representation of the solar radiation in Ujire.

\section{Working of Solar Cell}

Solar cells work to make light into electricity directly. When light shines, electrons are liberated in the p-type region and holes produced in the n-type region; this lowers the potential energy barrier at the junction. A current flows and establishes an external potential difference. Solar cells act in a way similar to the diode, so that current can flow in only one direction when the cell is exposed to light. Even though Becquerel discovered the effect in 1839, the first solar cell was made only in 1954 [7].

\section{III.EXPERIMENTAL SETUP}

A PV panel was mounted on a rectangular steel frame and the assembly was fixed to a pin joint (provided with a graduated angular scale) which could be used to fix the panel at any angular position with respect to horizontal. The setup, in turn, was mounted on a bearing so that it can be rotated with respect to vertical axis. Polycrystalline silicon solar cells are used in the investigation. The cells were inserted within an encapsulation with an air gap in between [8].

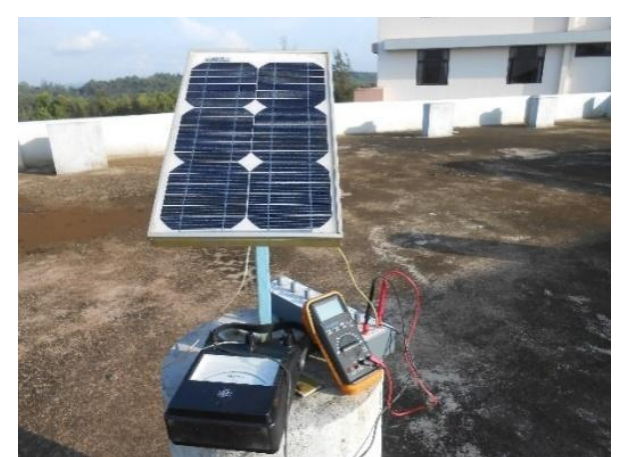

fig 1: Experimental Setup

\section{ELECTRICAL CIRCUIT}

as a load, for which a voltmeter connected in parallel, which formed a closed circuit.

Table 2: Specifications of the PV panel

\begin{tabular}{|l|l|}
\hline Company & Kotakujra Pvt. Ltd. \\
\hline Model number & KM 0010 \\
\hline Number of Cells & 36 \\
\hline Dimension & $445 \mathrm{~mm} \times 280 \mathrm{~mm} \times 30 \mathrm{~mm}$ \\
\hline Weight & $1.5 \mathrm{Kg}$. \\
\hline Cell material & Polycrystalline silicon \\
\hline
\end{tabular}

Table 3: Electrical specification of the solar PV panel

\begin{tabular}{|l|l|l|}
\hline $\begin{array}{l}\text { Sl. } \\
\text { No. }\end{array}$ & \multicolumn{1}{|c|}{ Item } & Value \\
\hline 1 & Open Circuit Voltage $\mathbf{V}_{\text {oc }}$ & $18.8 \mathrm{~V}$ \\
\hline 2. & Short Circuit current $\mathbf{I}_{\text {sc }}$ & $0.59 \mathrm{~A}$ \\
\hline 3 & Maximum Voltage $\mathbf{V}_{\max }$ & 17.64 \\
\hline 4 & Maximum Power at STC & $10 \mathrm{Watt}$ \\
\hline 5 & Maximum System voltage & $600 \mathrm{~V}$ \\
\hline 6 & Operating temp & $-40^{\circ} \mathrm{C}$ to $+85^{\circ} \mathrm{C}$ \\
\hline
\end{tabular}

\section{V.METHOD FOLLOWED}

\section{Case I}

First the experiment was carried out by measuring current and voltage on the solar panel mentioned above by varying the load resistance, three times a day. Pyranometer was used to calculate the solar radiation during that time of the day which was found to be $904.8 \mathrm{~W} / \mathrm{m}^{2}$. Then adding the same solar panel configuration in PSIM, the same procedure was conducted in simulation, the result was nearly the same as actual readings obtained in the solar panel the standard light intensity was taken as 1 Sun (where $1 \mathrm{Sun} \approx 1000 \mathrm{~W} / \mathrm{m}^{2}$ ).

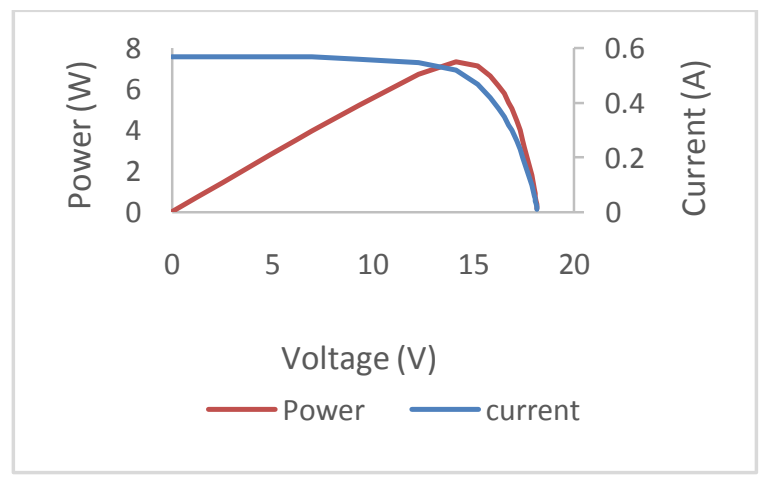

Fig. 2. IV and PV characteristics of the solar panel at 1 sun (actual)

Case II

Using the same simulation extrapolating the light intensity we increased the light intensity to 2 suns and the same

The solar panel [Table (1 and 2)] was connected to an ammeter, in series with a decade resistance box which acts 
Vol. 5, Special Issue 2, April 2017

method was carried out and the following readings were obtained.

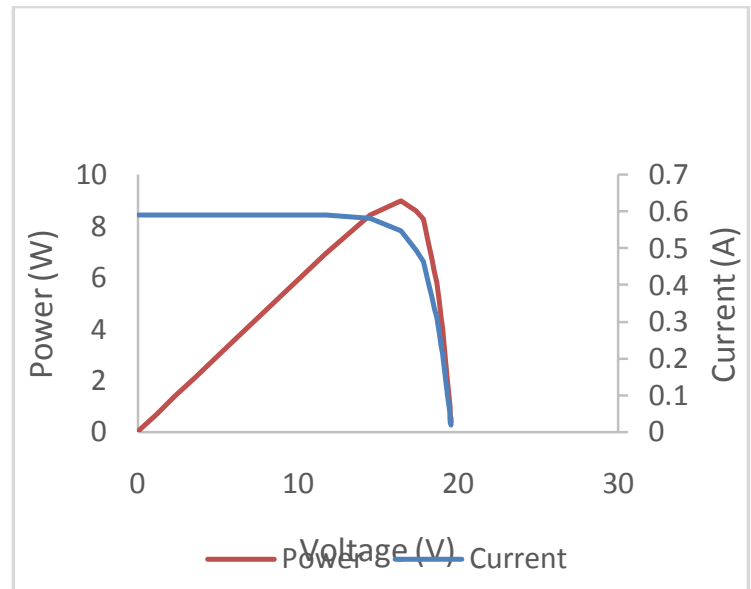

Fig. 3. IV and PV characteristics of the solar panel at 1 sun (simulated)

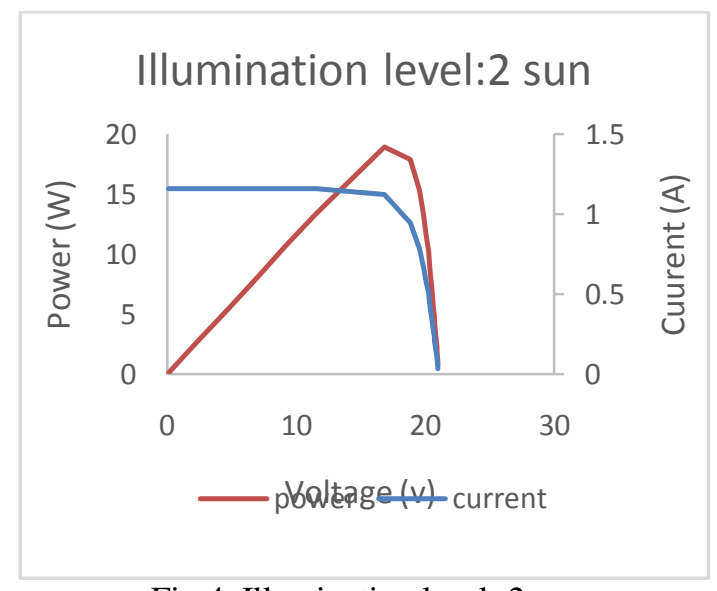

Fig.4. Illumination level: 2 sun

\section{Case III}

The same method was followed for 3 suns, and 5 sun and the following results were obtained.

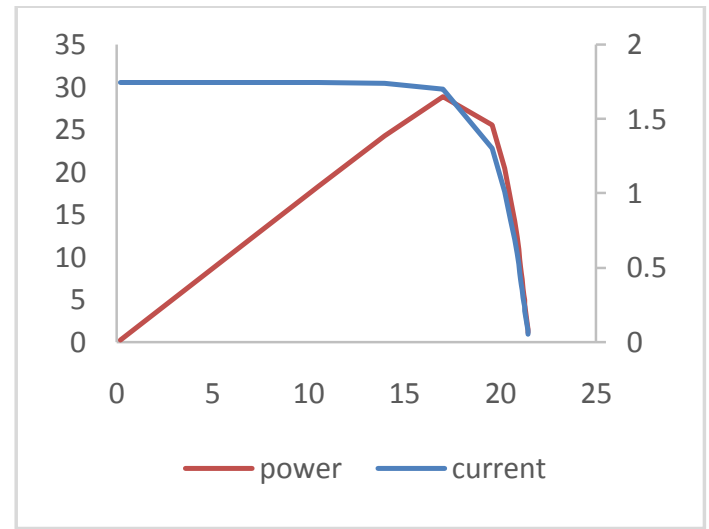

Fig. 5. Illumination level: 3 sun

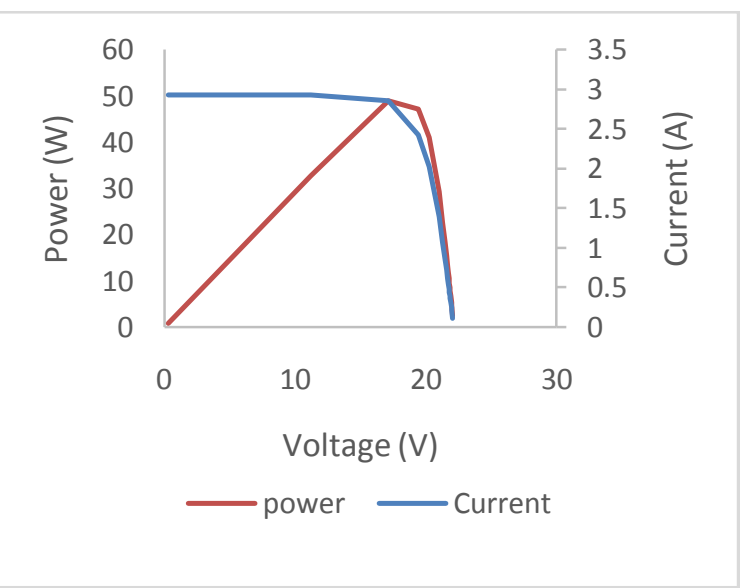

Fig. 6.Illumination level: 5 sun

\section{CONCLUSION}

After performing the experiment and comparing the real and simulated values, it is well known that, the efficiency of the solar panel remained constant even though the light intensity falling on the panel was increased, hence more output could be achieved by increasing the light intensity on the solar panel by the use of concentrators. [8]

\section{ACKNOWLEDGEMENT}

We would like to place our sincere gratitude towards Prof. Sathyanaranaya Bhat, Dept. of Electrical and Electronics, SDM Institute of Technology Ujire and Prof. Lakshmisagar Perla, Dept. of Physics, and Dr. Girish Kumar, HOD Mechanical dept., SDM Institute of Technology Ujire for their constant support and guidance.

\section{REFERENCES}

[1] Daniel W. Hart. Introduction to Power Electronics, Prentice Hall International, second edition 2008

[2] MiroZeman, Deft University of Technology. "INTRODUCTION TO PHOTOVOLT AIC SOLAR ENERGY"

[3] "Solar fuels and Artificial Photosynthesis "Royal Society of Chemistry 2012(http://www.rsc.org/ScienceAndTechnology/Policy/ Documents/solar-fuels.asp)

[4] "PRACTICAL HANDBOOK OF PHOTOVOLTAICS: Fundamentals and Application"-Tom Markvart\& Luis Castaner.

[5] MiroZeman, Deft University of Technology. "INTRODUCTION TO PHOTOVOLTAIC SOLAR ENERGY"

[6] http://www.synergyenviron.com/tools/solar_insolation.asp?loc=Uji re

[7] Gordon Aubrecht "THE PHYSICS OF SOLAR CELLS"

[8] Sathyanarayana P., Rajkiran Ballal, Girishkumar, Laksmisagar P.S. "Effect of Light concentration by flat mirror reflectors on the electrical power output of the photovoltaic panel". 
National Conference on Advances in Electrical Engineering

NMAM Institute of Technology, Nitte

Vol. 5, Special Issue 2, April 2017

\section{BIOGRAPHIES}

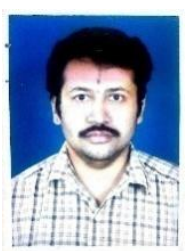

Mr. Sathyanarayana.P is an Assistant professor in Department of Electrical and Electronics Engineering, SDMIT, Ujire. He completed his BE and Mtech in VTU and pursuing PhD in VTU and his area of interest is renewable energy and power electronics.

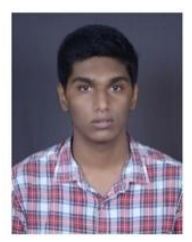

Mr. Abhishek.P.V currently pursuing Bachelor of Engineering in Electrical and Electronics at SDM Institute of Technology, Ujire.

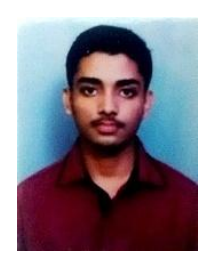

Mr. Sachin.K.Shetty currently pursuing Bachelor of Engineering in Electrical and Electronics at SDM Institute of Technology, Ujire

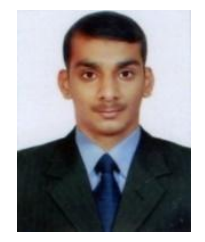

Mr. Sudhir Pai currently pursuing Bachelor of Engineering in Electrical and Electronics at SDM Institute of Technology, Ujire.

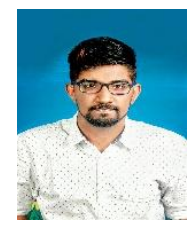

Mr. Srinidhi. M currently pursuing Bachelor of Engineering in Electrical and Electronics at SDM Institute of Technology, Ujire. 